\title{
Kemitraan Strategis Non-Zero Sum Game: Hubungan ASEAN-Australia dalam Konteks Geopolitik
}

\author{
Rio Akbar Pramanta, Roihanatul Maziyah, Dela Karisma, Putri Rahma Asri, \\ Ayu Tiara Karel Bua, Dimas Bagas Priambodo, dan Bayu Mahendra \\ Universitas Diponegoro
}

\begin{abstract}
ASEAN and Australia has a long history of mutual partnership. It is a strategic foreign policy for both parties. ASEAN needs to maintain its power and influence with their neighboring countries to maintain the political stability in the Southeast Asian region. On the other hand, Australia needs Southeast Asia because it serves as a strategic and crucial pivot of numerous benefits and interests for them, including but not limited to security and economics. However, ASEAN-Australia relations is not separated from the geopolitical implications. The geopolitical factors determine the strategic partnership between ASEAN and Australia, thus leading to the hypothesis in this article where Australia needs ASEAN more than the vice versa, and Australia is the one who benefits more in terms of relative gain, relative to ASEAN.
\end{abstract}

Keywords: ASEAN-Australia relations, neorealism, relative gain, geopolitics

\begin{abstract}
Abstrak
ASEAN dan Australia memiliki sejarah yang cukup panjang dalam hal kerjasama. Untuk kedua belah pihak, kerjasama ini adalah kebijakan luar negeri yang bersifat strategis. ASEAN harus menjaga kekuatan dan pengaruhnya pada negara-negara tetangga untuk menjaga stabilitas di kawasan Asia Tenggara. Australia membutuhkannya karena Asia Tenggara adalah kawasan penting dan vital untuk banyak kepentingan nasional Australia yang termasuk, namun tidak terbatas pada keamanan dan ekonomi. Tetapi, hubungan ASEAN-Australia tidak terlepas pada sifat geopolitis. Faktor-faktor geopolitik menjadi penentu dalam kemitraan strategis antara kedua pihak, di mana artikel ini mengajukan hipotesis bahwa Australia lebih membutuhkan ASEAN daripada sebaliknya, dan Australialah yang relatif lebih diuntungkan dalam hubungan ini.
\end{abstract}

Kata-kata kunci: hubungan ASEAN-Australia, neorealisme, relative gain, geopolitik 


\section{Pendahuluan}

Dunia perpolitikan internasional mengalami perubahan fokus yang cukup radikal dalam diskursus-diskursusnya. Pasca Perang Dingin usai, struktur perpolitikan negara-negara di dunia menjadi berubah, yang berawal dari bipolar menjadi multipolar. Saat ini, setiap kawasan di dunia berlomba-lomba untuk meningkatkan kekuatan dan menyebarkan pengaruhnya. Setiap kawasan memiliki kekuatan dan kelemahan yang berbeda dengan kawasan lainnya, sehingga terbentuklah sebuah interaksi dan hubungan politik antar negara yang lebih kompleks ketimbang pada era Perang Dingin (Waltz, 2000).

Asia Tenggara adalah kawasan yang memiliki potensi yang cukup besar ketika negara-negara di kawasan tersebut mengalami dekolonisasi pasca Perang Dunia II. Pada tahun 1967, dengan ditetapkannya Deklarasi Bangkok, Association of Southeast Asian Nations atau ASEAN terbentuk. Organisasi ini telah relatif berhasil dalam menciptakan stabilitas dalam kawasan Asia Tenggara dan sekitarnya. Seraya mengurusi masalah internal, ASEAN juga berusaha untuk meningkatkan pengaruhnya sebagai sebuah kawasan. Dengan segera, ASEAN merangkul kawasan-kawasan dan negaranegara yang bersifat vital untuk melakukan kerjasama guna meningkatkan kekuatan dan pengaruh sebagai sebuah kawasan. Salah satu negara yang menjadi partner kerjasama ASEAN tidak lain adalah tetangganya sendiri di bagian selatan, yaitu Australia.

Hubungan antara ASEAN dengan Australia sudah dimulai sejak tahun 1974 hingga saat ini. Hubungan di antara keduanya juga tidak selalu diwarnai dengan hubungan kerjasama yang harmonis. Akan tetapi, seiring berjalannya waktu, keduanya semakin menunjukkan sikap berkomitmen untuk memperdalam hubungan kerjasama satu sama lain. Hal itu salah satunya ditandai dengan disepakatinya Plan of Action (PoA) pada KTT peringatan 40 tahun kerjasama ASEAN-Australia di Myanmar, November 2014. PoA tersebut mengandung poin-poin kerjasama di beberapa bidang strategis yang rencananya dilakukan dalam jangka waktu lima tahun, terhitung sejak 2015 hingga 2019. Beberapa poin terkait kerjasama di bidang politik meliputi penguatan kerjasama melalui forum-forum yang dipimpin ASEAN, seperti East Asia Summit (EAS), ASEAN Post Ministerial Conference with Australia (PMC+1), ASEAN Regional Forum (ARF), ASEAN Defence Ministers' Meeting Plus (ADMM-Plus), ASEAN-Australia Forum, dan ASEANAustralia Joint Cooperation Committee; dan membangun kerjasama ASEANAustralia di dalam forum-forum multilateral seperti di forum-forum PBB, Asia Europe Meeting (ASEM), Asia Pacific Economic Cooperation (APEC), dan Group of Twenty (G20). Kemudian untuk bidang ekonomi, salah satu poin yang dibahas adalah mengenai kerjasama AANZFTA (ASEAN-AustraliaNew Zealand Free Trade Agreement). 
Pada awal tahun 2018 ketika diseleggarakannya Konferensi Tingkat Tinggi ASEAN di Sydney, Australia, Presiden Joko Widodo melontarkan pernyataan yang mengejutkan bahwa apabila Australia menjadi anggota ASEAN maka akan berdampak pada stabilitas ekonomi dan politik kawasan (Masola \& Hartcher, 2018). Pernyataan tersebut menuai berbagai tanggapan, karena hampir semua hal tentang Australia dan Asia Tenggara berbeda, baik dari segi sejarah, politik, ekonomi, dan budaya, meskipun keduanya memiliki aspirasi yang pada dasarnya sama, mereka mempunyai gaya yang berbeda dan kecepatan yang berbeda untuk mewujudkan aspirasi tersebut (Wood \& He, 2014). Bahkan, Anthony Milner (2012) dalam esainya yang berjudul Think Again about ASEAN, menyebutkan bahwa, "ASEAN tidak memiliki profil tinggi di Australia, berbeda dengan AS, Cina, atau India. Sebagian besar orang Australia tidak akan melihat ASEAN sebagai hal penting bagi masa depan geopolitik, dan para pemimpin ASEAN tampaknya mengetahui hal ini." Hal ini didukung oleh Walker \& Sobocinska (2012) dalam tulisannya yang berjudul Introduction: Australia's Asia, yang menyatakan bahwa sejak awal Australia merasa curiga dalam kaitannya dengan Asia. Dengan kata lain, narasi dominan bagi Australia adalah bahwa Asia dianggap sebagai ancaman, yang dibuktikan dengan disahkannya Undang-Undang Keimigrasian yang dikenal sebagai "White Australia Policy" (O’Neil, 2018). Namun di sisi lain, Australia juga melihat Asia sebagai wilayah dengan peluang tanpa batas, sehingga dapat dikatakan sebenarnya bahwa "antusiasme Australia untuk Asia sama tuanya dengan kecemasannya."

Hubungan antara ASEAN dan Australia menuju babak baru ketika pemerintahan Obama mengumumkan tentang kebijakan "pivot" (kembali) ke Asia pada tahun 2010. Kebijakan ini dikeluarkan dalam konteks di mana banyak sekutu AS di wilayah Asia menganggap bahwa Washington terlalu sibuk dengan Timur Tengah, sehingga mengorbankan keterlibatan AS di Asia-Pasifik. Persepsi ini diperkuat dengan fakta bahwa Cina telah membuat terobosan signifikan secara diplomatik dan militer di Asia Tenggara, selama periode ketika AS terlalu fokus pada Timur Tengah (O’Neil, 2018). Menteri Luar Negeri Hillary Clinton dalam sebuah artikel yang diterbitkan oleh Foreign Policy pada Oktober 2011, menyatakan bahwa: "In Asia, they ask whether we are really there to stay, whether we are likely to be distracted by events elsewhere, whether we can make-and keep-credible economic and strategic commitments, and whether we can back those commitments with action" (Clinton, 2011). Sebulan sebelumnya, Perdana Menteri Julia Gillard mengumumkan pengajuan Buku Putih tentang "Australia and the Asian Century," yang fokusnya adalah "on opportunities to increase the economic and other net benefits to Australia from the global, economic and strategic shift to Asia, in the short, medium and long term" (Department of the Prime and Cabinet, 2011). Hal ini 
kemudian diperkuat oleh pidato Obama di Parlemen Australia pada bulan November 2011, di mana dia menguraikan pentingnya kebijakan "Pivot to Asia" untuk memperdalam komitmen hubungan ekonomi dan politik di kawasan serta meyakinkan sekutu bahwa AS akan memenuhi komitmen keamanannya di masa depan (The White House, 2011). Sementara itu, ketika pemerintahan koalisi Tony Abbott berkuasa pada September 2013, Dennis Shanahan meyebutkan salah satu slogan menonjol dari kampanye elektoral Abbot, yaitu “Less Geneva and more Jakarta” (O'Neil, 2018).

Oleh karena itu, muncul sebuah pertanyaan yang mengarah pada hubungan ini. Apa yang membuat kerjasama ini menjadi sangat krusial bagi kedua belah pihak? Pihak manakah yang lebih diuntungkan? Apakah ASEAN juga diuntungkan sebagaimana Australia mendapat keuntungan dari kerjasama kedua belah pihak?

Artikel ini akan membahas dan mencoba menjawab pertanyaan ini menggunakan paradigma Neorealisme dan pendekatan secara geopolitik. Secara sistematis penulisan, pada sub-bab kedua artikel ini akan dijabarkan tentang kerangka pemikiran yang berangkat dari konsep geopolitik. Pada sub-bab ketiga akan dijabarkan tentang situasi geopolitik yang akan banyak mempengaruhi hubungan antara ASEAN dan Australia. Pada subbab keempat akan dipaparkan beberapa contoh konsekuensi atas situasi geopolitik tersebut dalam bidang keamanan dan ekonomi. Dan pada subbab kelima, hasil pembahasan pada artikel ini akan disimpulkan.

\section{Paradigma Neorealisme dalam Pendekatan Geopolitik}

Kembali pada era perpolitikan internasional lebih dari 20 tahun setelah perang dingin usai, negara-negara di dunia memasuki masa transisi. Ini adalah masa di mana bentuk hubungan konfrontasi atau kooperasi bisa saja mewarnai hubungan antar negara di dunia dan terjadi secara kontekstual. Ada sebuah konsep yang dikenal sebagai Kemitraan Strategis. Kemitraan strategis adalah bagaimana suatu kebijakan luar negeri sebuah negara berusaha mencari aliansi-aliansi, hubungan-hubungan, serta kerjasama yang bersifat strategis untuk menambah potensi tercapainya kepentingan nasional masing-masing.

Neorealisme adalah salah satu perkembangan dari teori-teori klasik hubungan internasional yang telah disesuaikan dengan perubahan situasi politik internasional. Dalam hal ini, aktor terpenting dalam melakukan hubungan dan berpolitik antar negara tetaplah kekuatan yang bersifat hard power dan materiil. Namun, karena adanya perubahan struktur politik internasional dan adanya perubahan kepentingan, terdapat beberapa konsep baru yang diperkenalkan untuk menyesuaikan dengan perubahan ini, diantaranya adalah konsep konsentrasi, polaritas, dan distribusi kekuasaan (Snyder, 1996). Konsep polaritas ini menjelaskan bahwa struktur 
poltik internasional berubah dengan adanya negara-negara atau kawasankawasan yang memiliki kekuatan dan pengaruh yang cukup signifikan, sehingga dapat membuat blok-blok kerjasama dengan negara-negara yang ingin dipayungi oleh polaritas tersebut. Di situlah terjadi konsentrasi dari kekuasaan dan pengaruh negara-negara yang tergabung pada blok tersebut. Kekuasaan yang terkonsentrasi itu kemudian terdistribusi secara merata pada negara-negara yang tergabung, sehingga negara-negara tersebut memiliki tambahan kekuatan untuk mencapai kepentingannya masingmasing (Mansfield, 1993).

Pada era Perang Dingin, polaritas ini terkonsentrasi pada Blok Barat dan Blok Timur yang masing-masing diwakili oleh AS dan Uni Soviet. Namun, setelah usainya Perang Dingin, polaritas ini berpindah pada kawasan-kawasan yang bersifat geografis. Meniru bagaimana Blok Barat memiliki sebuah institusi kerjasama yaitu North Atlantic Treaty Organization (NATO), dan Blok Timur dengan Organisasi Pakta Warsawa-nya, negaranegara di kawasan-kawasan ini pun membentuk sebuah institusi untuk mewadahi kepentingan mereka (Waltz, 2000). Hal inilah yang mendasari bagaimana organisasi regional seperti ASEAN, EU, atau Arab League terbentuk. Seperti yang telah dijelaskan sebelumnya, kebanyakan organisasi regional seperti ini juga dikendarai oleh faktor kekuatan dan pengaruh, diantaranya dengan membentuk sebuah organisasi yang dapat membuat distribusi konsentrasi kekuatan yang merata pada negara anggotanya masing-masing (Mansfield, 1993).

Kaum Neorealis mengakui adanya beberapa derajat taraf pentingnya peran institusi-institusi dalam hubungan internasional, meskipun tidak seoptimis kaum Neoliberalis. Neorealisme juga mengakui adanya institusi dan rezim internasional yang tumbuh subur pasca berakhirnya Perang Dunia II (Baldwin, 1993). Mereka percaya bahwa negara-negara terlibat dalam institusi-insitusi internasional dan kesepakatan-kesepakatan kerjasama ketika hal tersebut sesuai dengan kepentingan negara-negara yang bersangkutan. Secara sederhana, dapat dipahami bahwa institusi internasional bersifat penting hanya pada tahapan bahwa adanya kerjasama akan mengarahkan negara-negara untuk mendapatkan kepentingan dan memberikan keuntungan bagi mereka (Steans \& Pettiford, 2009). Menurut Kenneth Waltz, sistem internasional yang anarki menyebabkan negara lebih banyak memperhatikan keuntungan relatif daripada keuntungan absolut (Powell, 1991).

Realitasnya, keadaan perpolitikan internasional tidaklah melulu konstan dalam kondisi peperangan, tetapi juga kondisi di mana negaranegara melakukan kerjasama. Kerjasama ini terjadi karena adanya faktorfaktor eksternal menghasilkan sebuah ketergantungan antar negara, seperti contohnya faktor geografis. Artinya, saat ini kemitraan strategis yang 
memungkinkan adanya fleksibilitas dalam menjalankan kepentingan luar negeri memang sangat dibutuhkan apabila ingin mencapai apa yang disebut sebagai kepentingan nasional. Dalam hal ini, hubungan kerjasama antara ASEAN dan Australia dibutuhkan demi mencapai kepentingan kedua belah pihak, baik dalam sisi politik, ekonomi, maupun dalam hal geopolitik (Mamadouh \& Dijkink, 2006). Terkadang, kita tidak bisa memaksa untuk mengaplikasikan hanya satu teori untuk beberapa konteks yang berbeda, meskipun objek kajiannya sama. Hubungan antara ASEAN dan Australia memiliki dinamika yang unik, di mana relasi antar dua belah pihak dalam konteks geopolitik dan konteks poltik-ekonomi menjadi dua bahasan yang bisa sangat berbeda.

Jack Donelly (dalam Burchill, 2013) mengatakan: "Relative gains dramatically impede cooperation, one must consider not only whether one gain, but more importantly, whether one's gains outweigh those of others, who in anarchic world, must be seen as potential adversaries."

Pernyataan tersebut memberi arti bahwa relativitas kekuatan bukan absolutisme kekuatan. Bagi neorealis, apabila dua negara terlibat dalam perjanjian perdagangan atau perjanjian militer, meskipun kedua negara tersebut sama-sama mendapatkan keuntungan, tetapi apabila ada satu pihak lebih diuntungkan dibandingkan dengan pihak lain, maka pihak yang 'lemah' tersebut harus merasa skeptis karena ada pihak yang lebih diuntungkan 'stronger state'. Singkatnya, neorealis memandang kerjasama internasional sebagai sebuah keuntungan yang sifatnya relatif. Lipson (dalam Baldwin, 1993) menambahkan, bahwa keuntungan relatif cenderung lebih diutamakan dalam masalah keamanan daripada dalam urusan ekonomi.

Hubungan ASEAN dan Australia dalam konteks geopolitik bersifat deterministik karena berkaitan erat dengan kondisi fisik. Baik Australia maupun ASEAN tidak dapat memilih lokasi geografis mereka, sehingga mereka harus make-do, menemukan cara untuk memaksimalkan potensi yang ada pada aspek geografis mereka. Sementara itu, dalam konteks politik-ekonomi, hubungan kedua pihak cenderung relativistik karena memang perlu diakui, titik mulai dan modal awal kedua pihak dalam perpolitikan internasional memiliki perbedaan yang cukup signifikan. Karena inilah, hubungan antara ASEAN dan Australia bukan merupakan hubungan yang bersifat sempurna atau keuntungan mutlak, melainkan sebuah hubungan yang memiliki sifat keuntungan relatif karena harus ada kompensasi-kompensasi tertentu yang menutup kelemahan yang disebabkan oleh faktor-faktor eksternal. 


\section{Tinjauan Geopolitik Hubungan ASEAN dan Australia}

Meskipun kawasan Asia Tenggara merupakan sebuah kawasan yang strategis, secara relatif, Australia tidak memiliki posisi geografis yang strategis. Sebagai negara persemakmuran Inggris dan hasil kolonialisme Eropa pada jamannya, Australia terletak jauh dari sekutu-sekutunya. Karena faktor letak geografis ini, Australia harus memanfaatkan satu-satunya gerbang keluar dan masuk Asia, yaitu kawasan Asia Tenggara, dan ASEAN sebagai organisasi yang menguasai kawasan tersebut (Rumley, 2001). Hal ini dapat diartikan secara literal atau figuratif. Baik dari sisi politik di mana ASEAN menjadi organisasi yang cukup berpengaruh di Asia, maupun dari sisi teknis yang mana banyak jalur perdagangan dan transportasi menuju dan dari Australia yang harus melewati negara-negara ASEAN terlebih dahulu.

Australia membutuhkan ASEAN karena ASEAN adalah partner strategis dalam hal geopolitik. ASEAN merupakan sebuah benteng geografis dalam hal pertahanan, karena ancaman apapun yang datang dari arah Asia, harus melewati Asia Tenggara terlebih dahulu sebelum mencapai Australia. Australia senantiasa melakukan latihan bersama dengan angkatan-angkatan bersenjata negara-negara ASEAN. Pemerintah Australia juga berinisiasi untuk meningkatkan kerjasama dalam bidang pertahanan militer dan keamanan dengan negara-negara ASEAN, terutama Indonesia, karena sifatnya yang sangat strategis dalam hal pertahanan secara geografis (Frost, 1983).

Dalam hal perdagangan internasional, negara-negara ASEAN banyak yang memiliki kota-kota pelabuhan yang berfungsi sebagai shipping $h u b$, yang akan terhubung juga ke Australia. Keberadaan shipping hub ini pada dasarnya meningkatkan efisiensi perdagangan dan memangkas biaya dibandingkan dengan pengiriman langsung dari negara asal. Hal ini semakin dipermudah dengan pembentukan ASEAN Free Trade Area (AFTA), serta diusungnya ASEAN Economic Community (AEC), di mana Australia dapat mengakses pasar di ASEAN secara langsung tanpa harus melakukan perjanjian atau diplomasi bilateral dengan negara-negara di ASEAN. Hubungan kerjasama dalam hal ekonomi dan perdagangan antara ASEAN dan Australia meningkat sejak Australia secara resmi menjadi salah satu Dialog Partners pada tahun 1974. Pembahasan tentang kerjasama dalam bidang ekonomi akan dibahas lebih lanjut di bagian lain.

Kawasan Asia Tenggara juga berfungsi sebagai sebuah pijakan pertama Australia menuju Asia. ASEAN telah berhasil membangun sebuah pengaruh besar di kawasan Asia Tenggara, sehingga kawasan tersebut dianggap sebagai kawasan yang vital dan strategis, terutama untuk kawasan-kawasan lain di Asia, seperti Asia Timur maupun Asia Selatan. Selain vital untuk Australia, Asia Tenggara juga menjadi kawasan yang vital 
untuk sekutu-sekutu Australia seperti AS yang memiliki anggapan bahwa Asia Tenggara merupakan kawasan yang strategis (Simon, 1992). Hal ini dibuktikan dengan adanya kebijakan luar negeri AS yang menyatakan bahwa Asia Tenggara adalah "A Pivot to Asia", sebuah patokan bagi Australia dan sekutu-sekutunya untuk memasuki kawasan Asia secara umum (Campbell \& Andrews, 2013).

Sebagai kawasan yang berhubungan langsung dengan Asia untuk Australia, Asia Tenggara juga berfungsi sebagai buffer zone terhadap ancaman dan pengaruh-pengaruh musuh politik Australia dan sekutusekutunya. Salah satu musuh Australia dan sekutunya yang sedang gencar meningkatkan keberadaan dan pengaruhnya di kawasan Asia Tenggara adalah Cina. Cina sedang giat memperluas pengaruhnya melalui ekspansi ekonomi. Asia Tenggara dan ASEAN menjadi entitas yang sangat krusial sebagai bantalan konflik kepentingan di antara kedua negara ini. ASEAN ibarat sebuah trofi yang diperlombakan, karena sifatnya sebagai buffer zone, ASEAN memiliki peran yang cukup berpengaruh untuk menambah atau mengurangi kekuatan dan pengaruh salah satu pihak (Menon \& Snyder, 2017).

Australia yang secara geografis terisolir dari kebanyakan sekutunya, harus menjaga pengaruhnya di kawasan Asia Tenggara agar tidak kalah oleh Cina. Hal ini juga disokong oleh bagaimana Australia menjadi home base bagi sekutu-sekutunya untuk masuk ke Asia melalui kawasan Asia Tenggara, seperti bagaimana dijelaskan dalam konsep "Pivot to Asia" (Tow, 2017). Meskipun Cina kurang bisa dianggap sebagai ancaman secara fisik untuk Australia karena zona panas dengan Cina di Asia Tenggara adalah Laut Cina Selatan dan Australia tidak punya akses secara langsung, Cina merupakan ancaman yang bersifat politis. Ketidakseimbangan pengaruh di kawasan Asia Tenggara dengan Cina yang semakin mendominasi dapat berpotensi menyulitkan Australia untuk mencapai kepentingannya (Syailendra, 2017).

Namun, berbeda halnya apabila kita memandang dari sudut pandang negara-negara Asia Tenggara dan ASEAN itu sendiri sebagai sebuah institusi. Meskipun secara prinsip ASEAN harus menggandeng negara-negara mitra yang berpotensial untuk bekerjasama, namun karena letak geografisnya yang strategis dan vital, ASEAN-lah yang akan dicaricari oleh banyak pihak sebagai target kerjasama.

Hal ini berlaku untuk Australia dan Cina. Dapat dikatakan bahwa kehadiran Australia di Asia Tenggara tidak begitu menguntungkan bagi ASEAN. Australia hanya memandang dirinya sebagai bagian dari kawasan berdasarkan pandangan geografis dan takdir semata. Sedangkan secara kepentingan strategis dan kebijakan luar negeri, Australia memilih untuk condong ke Barat, terutama AS. Sementara, Cina secara historis sudah 
memiliki hubungan dengan Asia Tenggara yang hingga sekarang masih sangat bergantung pada aksesibilitas perairan di Asia Tenggara. Sengketa Laut Cina Selatan adalah contoh bagaimana Cina berusaha memperluas pengaruh dan kekuatan secara fisik di kawasan Asia Tenggara.

Tetapi hal ini tidak mengindikasikan bahwa Asia Tenggara dan ASEAN dapat sewenang-wenang dalam melakukan hubungan antar negara. ASEAN harus tetap menjaga hubungan dengan negara-negara yang berbatasan langsung dengan kawasannya untuk menjaga stabilitas di kawasan tersebut. Stabilitas itu dapat diartikan dalam berbagai macam konsep, bisa dalam hal pengaruh, kekuatan, ataupun dalam hal keamanan (Goh, 2008). Terlebih, ASEAN harus memperhitungkan fakta bahwa Australia adalah sekutu AS dan Inggris yang juga memiliki kepentingan yang vital. Meskipun keuntungan yang akan didapat bersifat relatif, ASEAN dituntut untuk menjaga relasi dengan Australia. Dalam menjaga relasi ini, dilakukan berbagai cara soft-diplomacy, seperti contohnya melakukan kerjasama dalam bidang ekonomi maupun keamanan.

\section{Kerjasama ASEAN dan Australia dalam Bidang Keamanan dan Ekonomi}

Sejak dibentuknya ASEAN hingga sekarang, sebenarnya Australia masih lebih membutuhkan ASEAN daripada ASEAN membutuhkan Australia. Persepsi ASEAN terhadap Australia sebagai non-image membuat ASEAN tidak termasuk ke dalam daftar prioritas diplomatik dan menganggap bahwa Australia masih menempatkan hubungannya dengan 'negara induknya', Inggris, di atas negara tetangganya ASEAN-nya (Nicholas, 1983). Meskipun demikian, Perdana Menteri Australia, George Whitlam, menyambut ASEAN dalam pidatonya dengan, "the most wholesome and natural development in our area" dan mengatakan bahwa, "Australia would find it possible to be more closely associated with ASEAN" (Whitlam, 1967).

Beberapa pengamat Australia juga memandang ASEAN sebagai aliansi militer potensial karena Menteri Luar Negeri Australia menyatakan, "Australia would regard a defense role for ASEAN as a healthy development" (Frost, 1983). Seiring dengan perkembangan konstelasi hubungan internasional yang tidak hanya berkutat pada hubungan tradisional antar negara, ASEAN menaruh perhatian pada Australia di isu ekonomi dengan menggandeng Australia sebagai mitra strategis ASEAN (ASEAN Dialog Partners) yang pertama pada tahun 1974. Hubungan ASEAN dengan mitra eksternal ASEAN Dialog Partners disusun berdasarkan kapasitas para mitra tersebut untuk mendukung pembangunan ASEAN dalam hal sumber daya dan keahlian (Thuzar, 2017). Keputusan akhir tentang penentuan mitra eksternal ini bertumpu pada KTT ASEAN dan membutuhkan persetujuan dari semua negara anggota ASEAN. Dengan diputuskannya Australia sebagai mitra strategis pertama ASEAN, berarti ASEAN tertarik dan menawarkan komitmen dengan Australia untuk bekerjasama. 
Keinginan ASEAN untuk bekerjasama dengan Australia mencerminkan apresiasi terhadap kebijakan luar negeri Australia selama ini terhadap ASEAN (Frost, 1983). Perkembangan fenomena global dan meningkatnya peran aktor non-negara dalam hubungan internasional memunculkan sebuah kesamaan ancaman antara ASEAN-Australia, yaitu dalam isu kemanusiaan dan kejahatan transnasional. Isu kemanusiaan menjadi semakin penting dalam konteks ASEAN-Australia, karena menimbulkan ancaman signifikan terhadap keamanan dan stabilitas kedua pihak. Eksodus pengungsi dari Vietnam dan negara-negara IndoCina lainnya memberikan dampak besar bagi negara ASEAN, terutama Thailand, Malaysia, dan Indonesia (Frost, 1983). Di sisi lain, kebijakan imigrasi dan pengungsi Australia yang terbatas mendorong ASEAN dan Australia untuk bekerjasama dalam membagi beban ekonomi dan administrasi, serta meredam ketegangan sosial dan politik. Kedua pihak mengadopsi kebijakan aktif untuk saling bekerjasama dan berusaha untuk 'menginternasionalkan' masalah pengungsi ini.

Selain itu, isu kejahatan transnasional merupakan ancaman bersama ASEAN-Australia. Isu penyeludupan manusia, perdangangan narkoba, dan terorisme adalah isu yang mempererat hubungan dan kerjasama ASEAN-Australia. Sejak tragedi 9/11, AS tampaknya telah menyadari kesalahannya mengabaikan Asia Tenggara dalam agenda strategisnya. Dengan demikian, AS telah memutuskan untuk membawa Asia Tenggara kembali ke radar strategisnya dan menyatakan kawasan itu sebagai front kedua dalam perang melawan terorisme (Banlaoi, 2003). Sebagai sekutu AS, Australia kemudian menjadikan terorisme sebagai isu sentral dalam menentukan hubungan Australia dengan negara-negara Asia Tenggara.

Sejak September 2001, Australia memfokuskan kerja sama di bidang counterterrorism dengan memberikan bantuan politik, militer, dan pembangunan. Australia juga telah merundingkan tidak kurang dari 12 "memorandum of understanding" bilateral mengenai kerja sama kontraterorisme dengan negara-negara Asia dan Pasifik, menyelenggarakan empat KTT regional tingkat menteri, dan menyediakan lebih dari US $\$ 100$ juta dalam berbagai proyek bantuan untuk membantu upaya anti-terorisme (Ungerer, 2006). Kerjasama ASEAN-Australia diwujudkan dalam sebuah Joint Statement, yaitu Deklarasi Sydney 2018, yang menunjukkan komitmen untuk menjaga keamanan regional mencakup penegakan hukum pidana antar negara, pengamanan beacukai dan imigrasi untuk mengatasi kejahatan lintas negara, dan pentingnya non-militerisasi dalam mencapai resolusi damai, khususnya terorisme.

Terorisme menjadi isu hangat kedua pihak karena motif kasus terorisme di ASEA-Australia hampir sama. Di awal masa pemerintahan Perdana Menteri Turnbull, tindakan terorisme karena alasan agama semakin 
banyak terjadi di Australia, seperti Penembakan Parramatta tahun 2015 yang pelakunya adalah seorang pria kelahiran Irak yang gemar mendengarkan ceramah Hizbut Tahrir. Selain itu, pelaku serangan Penikaman Minto 2016 bernama Ihsas Khan, yang disebutkan oleh polisi setempat bahwa dia terinspirasi oleh ISIS dan mengakui pelaku penembakan Parramatta sebagai panutan. Bersamaan dengan itu, terjadi tindakan terorisme di Indonesia oleh Mujahidin Indonesia Timur (MIT) tahun 2015 atas pembunuhan tiga warga sipil dan tewasnya anggota polisi dalam aksi penembakan dengan seorang tersangka teroris MIT (US Department of State, 2015).

Menurut ASEAN, keberhasilan institusi ini terletak pada sifatnya yang terbuka, inklusif, dan berwawasan ke luar. Untuk mencapai tujuan tersebut, ASEAN telah membentuk Dialog Partner dengan sepuluh mitra, salah satunya Australia. Kedua pihak sama-sama mendapatkan keuntungan dari hubungan dan kerjasama ini. ASEAN telah memperoleh manfaat dari kerjasama dengan Australia, terutama dalam bidang ekonomi dan memberikan kesempatan pada ASEAN untuk mendiskusikan isu-isu baru seperti pengungsi dan terorisme yang berguna bagi kebaikan bersama. Bagi Australia, hubungan dengan ASEAN memiliki dampak positif karena membantu keamanan teritorialnya. Bekerjasama dengan ASEAN juga memberi pandangan kepada Australia bahwa netralitas ASEAN yang tidak perlu memilih antara AS atau China memberi dampak positif pada hubungan penuh-aliansi Australia dengan negara-negara besar.

Dalam konteks kerjasama ekonomi, ASEAN dan Australia memiliki hubungan kerjasama yang cukup erat. Berdasarkan data dari ASEAN Secretariat's Information Paper, diketahui bahwa proyeksi perdagangan ASEAN dengan Australia adalah sebesar US\$46,5 miliar pada tahun 2016, yang menjadikan Australia sebagai mitra dagang terbesar ketujuh ASEAN. Australia menjadi sumber investasi asing (FDI) terbesar keenam untuk ASEAN, dengan proyeksi FDI di angka US\$3,4 miliar dollar pada tahun 2016. Di sektor pariwisata, lebih dari 4,1 juta warga Australia mengunjungi ASEAN pada tahun 2015, menjadikan Australia sebagai sumber pendapatan pariwisata terbesar ke- 5 untuk ASEAN. ASEAN juga merupakan organisasi regional yang sangat penting bagi kesejahteraan ekonomi Australia. Sebagai satu kesatuan, ASEAN merupakan mitra dagang terbesar ketiga bagi Australia dengan tingkat perdagangan mencapai angka 15\% dari total perdagangan Australia. ASEAN juga memiliki populasi usia kerja yang sangat besar, yaitu sekitar 630 juta orang sehingga memungkinkan untuk adanya peningkatan ekonomi di masa yang akan datang. Selama 15 tahun terakhir, gabungan ekonomi ASEAN telah meningkat empat kali lipat menjadi US $\$ 2,5$ triliun, dengan rata-rata pertumbuhan pasar sekitar 4,5\%, menjadikannya salah satu dari tiga pusat pertumbuhan global teratas. 
Dapat dilihat bahwa kedua pihak, baik ASEAN maupun Australia, sama-sama diuntungkan, bahkan neraca perdagangan ASEAN dengan Australia menunjukkan surplus sejak tahun 2011 hingga 2016. Dengan demikian, data tersebut menyatakan bahwa dalam bidang ekonomi, kerjasama di antara keduanya sama-sama membawa keuntungan satu sama lain, meskipun terdapat perbedaan tingkat keuntungan. Hal ini sejalan dengan konsep relative gain dalam perspektif Neorealisme dalam hubungan internasional. Hal tersebut menunjukkan arah gerak kemitraan strategis di antara keduanya, terutama dalam bidang politik dan ekonomi, menuju ke arah yang positif.

Keuntungan yang diperoleh Australia dari ASEAN melalui kerjasama dalam bidang pertahanan relatif lebih besar dibandingkan dengan keuntungan yang diperoleh melalui kerjasama ekonomi. Di sisi lain, ASEAN memperoleh keuntungan yang lebih kecil daripada Australia berkaitan dengan kerjasama dalam kedua bidang tersebut. Namun bagi ASEAN, kerjasama dalam kedua bidang ini merupakan kerjasama yang bersifat strategis, dengan Australia sebagai mitra strategisnya. Seperti yang telah dibahas di sub-bab sebelumnya, ASEAN harus menjaga relasi dengan Australia untuk kepentingan strategis guna mencegah gejolak-gejolak politik di kawasan Asia Tenggara yang tidak perlu dan dapat dihindarkan.

Australia melihat ASEAN tidak hanya sebagai mitra karena faktor kedekatan geografi atau takdir semata, tetapi lebih dari itu. Australia memandang ASEAN sebagai mitra yang strategis. Selain dipandang strategis dari segi geopolitik, ASEAN juga menjanjikan secara ekonomi bagi Australia. Pada tahun 2012 dan 2013, misalnya, perdagangan Australia dengan ASEAN (sebagai satu entitas) menyumbang 14,8 persen dari total perdagangan Australia yang berarti berada pada posisi kedua setelah Cina (21,1 persen) dan di atas Jepang (11,2 persen) dan jauh di atas dari AS (8,7 persen). Hal ini didasarkan pada prediksi bahwa Asia Tenggara adalah salah satu wilayah yang paling cepat berkembang dalam ekonomi global dengan ekspansi besar yang harus diantisipasi selama dua dekade mendatang (Biswas, 2014).

Dari uraian diatas, dapat dilihat bahwa motivasi Australia di ASEAN dilatarbelakangi oleh urusan geopolitik dan ekonomi semata. Australia sebagai sekutu AS dan negara yang sama-sama berakar dari budaya AngloSaxon (The Independent, 1999) tentunya akan mendukung kebijakan "Pivot to Asia" yang dicetuskan Obama. Disisi lain, Australia juga memiliki kepentingan tersendiri di Asia Tenggara, mengingat besarnya potensi sumber daya alam dan pertumbuhan ekonomi kawasan yang memiliki tren positif (Global-is-Asian, 2018). 


\section{Kesimpulan}

Pembentukan kerjasama ASEAN-Australia sejak awal tampaknya memberikan hasil yang positif bagi kedua belah pihak. Hal ini dibuktikan pada fase awal, dengan adanya investasi Australia bagi ASEAN cukup membantu membangkitkan pertumbuhan ekonomi dan pembangunan sosial yang ada di ASEAN ditengah-tengah isu keamanan pangan saat itu. Tidak hanya itu, kerjasama antar keduanya terus berlanjut secara terusmenerus melalui pelaksanaan berbagai proyek besar dalam berbagai aspek, baik dalam bidang perdagangan, iptek, peningkatan sumber daya manusia dalam bidang pertanian, hingga pada peningkatan kualitas hidup dan human security.

Namun seiring berjalannya waktu, beberapa anggota ASEAN sempat bersitegang dengan Australia, seperti Indonesia, Malaysia dan Singapura. Contohnya, ketika Australia dan Indonesia menghadapi isu terorisme, imigran gelap, dan ketidakjelasan batas wilayah kemaritiman. Meskipun dalam perjalanannya hubungan kerjasama ASEAN-Australia tidak selalu berjalan dengan mulus, kedua pihak tersebut terus memperdalam kerjasamanya, khususnya dalam bidang politik dan ekonomi. Seperti yang telah dijelaskan sebelumnya bahwa dengan adanya kemitraan strategis, fleksibilitas sangat memungkinkan untuk dilakukan demi mencapai kepentingan nasional. Sebagai bukti, keduanya telah menyepakati Plan of Action, yang didalamnya dibahas mengenai peningkatan kerjasama dalam berbagai bidang-bidang yang strategis. Kehadiran Australia di tengahtengah hubungan antar anggota ASEAN untuk campur tangan dalam berbagai isu-isu yang dihadapi ASEAN menunjukkan bahwa Australia membawa keuntungan yang besar. Australia menjadi investor terbesar keenam bagi ASEAN dan menjadi sumber pendapatan terbesar kelima dalam sektor pariwisata. Sementara bagi Australia sendiri, ASEAN juga menjadi mitra dagang terbesar ketiga.

Asia tenggara adalah kawasan yang menjadi persimpangan antar benua dan kawasan lain, dan ASEAN sebagai organisasinya membutuhkan jaminan kestabilan dan keamanan regional dengan negara-negara sekelilingnya. Kepentingan utama ASEAN dengan Australia sematamata hanya karena fakta geografis dan adanya interaksi Australia dengan negara-negara Asia Tenggara. Oleh karena itu, dapat dikatakan bahwa Australia mendapatkan keuntungan yang lebih besar daripada negaranegara Asia Tenggara atau ASEAN itu sendiri, karena Australia jauh lebih membutuhkan ASEAN sebagai pijakan menuju Asia, daripada sebaliknya. 


\section{Daftar Pustaka}

Baldwin, D. (1993). Neorealism and Neoliberalism: The Contemporary Debate. Columbia: Columbia University Press.

Banlaoi, R. C. (2003). Southeast Asian perspectives on the rise of China: regional security after 9/11. Parameters, p. 98.

Biswas, R. (2014). Global Recovery Should Carry ASEAN through Economic

Headwinds [Online], Forbes, 19 January. Tersedia di: <http://www.forbes. com/sites/forbesasia/2014/01/19/globalrecovery-should-carry-asean-through -economic-headwinds/> [diakses 25 Desember 2018].

Burchill, S. et. all., (2013). Realism in Theories of International Relations, 29-54. London: Macmillan International Higher Education.

Campbell, K, \& Brian A. (2013). Explaining the US 'Pivot' to Asia. Chatham House, pp. 7-8.

Clinton, H. (2011). America's Pacific Century. [Online], Foreign Policy, 11 October. Tersedia di: >http://foreignpolicy.com/2011/10/11/americas-paci> [diakses 24 September 2018].

Department of the Prime and Cabinet. (2011). Australia in the Asian Century:Issue Paper. Australian Broadcasting Corporation, p. 16.

Dobell, G. (2018). ASEAN and Australia go to the summit. Australian Journal of International Affairs, p.17.

Frost, F. (1983). ASEAN and Australia. Dalam: Broinowski, Alison. Understanding ASEAN, pp. 144-168. London: The Macmillan Press L TD.

Global-is-Asian. (2018). ASEAN Economic Trends in 2018. Singapore: Lee Kuan Yew School of Public Policy.

Goh, E. (2008). Great Powers and Hierarchical Order in Southeast Asia: Analyzing Regional Security Strategies. International Security, pp. 113-157.

Mamadouh, V. \& dan Gertjan D. (2006). Geopolitics, International Relations, and Political Geography: The Politics of Geopolitical Discourse. Geopolitics, pp. 349-366.

Mansfield, E. D. (1993). Concentration, Polarity, and the Distribution of Power. International Studies Quarterly, pp. 105-128.

Massola, J. \& Peter H. (2018). Indonesian President Widodo Says Australia Should Join ASEAN. [Online] Sydney Morning Herald, 15 Maret. Tersedia di: >https://www.smh.com.au/world/asia/indonesian-president widodo-saysaustralia-should-be-in-asean-20180315-p4z4ha. html.> [diakses 24 September 2018].

Menon, R. \& Jack L. S. (2017). Buffer Zones: Anachronism, Power Vacuum, or Confidence Builder? Review of International Studies, pp.962-986.

Nicholas, R. (1983). Misperception and Muddled Thinking in Australia ASEAN Relations. Contemporary Southeast Asia, 5 (2), p.153. 
O’Neil, A. (2018). Less Geneva, More Jakarta: Assessing Australia's Asia Pivot. Dalam: Rozman, Gilbert, et.all., International Relations and Asia's Southern Tier: ASEAN, Australia, India, pp. 261-273. Washington DC: Palgrave Macmillan.

Powell, R. (1991). Absolute and Relative Gains in International Relations Theory. American Political Science Review, pp.1303-1320.

Rumley, D. (2001). The geopolitics of Australia's Regional Relations. Berlin: Springer Science \& Business Media.

Simon, S. W. (1992). The Regionalization of Defence in Southeast Asia. The Pacific Review, pp. 112-124.

Snyder, G. H. (1996). Process Variables in Neorealist Theory. Security Studies, pp. 167-192.

Steans, Jill, \& Lloyd P. (2009). Hubungan Internasional: Perspektif dan Tema. Yogyakarta: Pustaka Pelajar.

Syailendra, E. A. (2017). A Nonbalancing Act: Explaining Indonesia's Failure to Balance Against the Chinese Threat. Asian Security , pp. 237-

255.

The Independent. (1999). Why Anglo-Saxon nations have the fastest-growingeconomies [Online], 3 September . Tersedia di: $<$ https:// www.independent.co.uk/news/business/why-anglo-saxon-nations-have-the-fastest-growing-economies-1115774.html> [diakses 24 September 2018].

The White House. (2011). Remarks by President Obama to the Australian Parliament, Canberra [Online], 17 November. Tersedia di:<http:// www.whitehouse.gov/the-press-office/2011/11/17/remarks-president-obama-australian> [diakses 24 September 2018].

Thuzar, M. (2017). What Does it Take to Join ASEAN? ISEAS Yusof Ishak Institute, 36, p.1.

Tow, W. T. (2017). President Trump and the Implications for the Australia-

US Alliance and Australia's Role in Southeast Asia. Contemporary Southeast Asia: A Journal of International and Strategic Affairs, pp. 50-57.

Turnbull, M. (2018). Opening Remarks at the ASEAN-Australia Special Summit Plenary Session [Online], 18 Maret. Tersedia di: <https:// www.pm.gov.au/media/openingremarks-asean-australia-special summit-plenary-session> [diakses 24 September 2018].

Ungerer, C. (2006). Australia's Policy Responses to Terrorism in Southeast Asia. Global Change, Peace E Security, pp. 193-199.

US Department of State. (2015). Country Reports: East Asia and Pacific Overview on Terrorism 2015 [Online]. Tersedia di: <https://www.state. gov/j/ct/rls/crt/2015/257515.htm.> [diakses 26 September 2018].

Waltz, K. N. (2000). Structural realism after the Cold War. International Secu- 
rity, 5 (1), pp. 5-41.

Whitlam, G. (1967). HoR, Conclusion, Suspension of Standing Order Speech [Online], Authority of the House of Presentative, 5 Juni. Tersedia di: <https://parlinfo.aph.gov.au/parlinfo/download/hansard80/ha sardr80/1975-0605/toc_pdf/19750605_reps_29_hor95.pdf> [diakses pada 27 September 2018].

Wood, S. P. \& Baogang H. (2014). The Australia ASEAN Dialogue Tracing 40 Years of Partnership. New York: Palgrave Macmillan. 